UK government's plans to split teaching and research

London

FunDs for teaching and research in universities should be allocated separately, says the British government. But the universities are not so sure. And the issue refuels the debate over the link between excellence in teaching and in research which looks set to be top of the agenda in future discussions between the academic community and the government.

Mr Kenneth Baker, the Secretary of State for Education and Science, delivered the government's message to the universities Committee of Vice-Chancellors and Principals (CVCP) at their annual meeting last week. After the meeting, vicechancellor of the University of Bristol, Sir John Kingman, called Baker's message an "extremely sinister development". "Most vice-chancellors are uneasy about it. It could destroy the quality of universities in Britain."

The crucial decisions on funding will be made in the course of negotiations between the universities, the new Universities Funding Council and the government, next year. For their part, universities are willing to provide services which reflect the funds allocated, and for the quality of the service to be monitored. What they will not tolerate, said Kingman, is interference in the way universities achieve that quality.

But Baker said that separation of funding would raise standards by allowing some academics to concentrate on research and others to concentrate on teaching and administration. He said more emphasis should be placed on teaching, and that "universities should assign to teaching the prestige they have traditionally assigned to research".

Later in the week, the CVCP said it is setting up a new academic standards unit which will review procedures for monitoring and improving academic standards and offer advice to individual institutions The CVCP also plans to undertake a study of teaching costs and prices similar to that undertaken recently for research.

Baker said he recognized that various practical questions would have to be answered before a scheme for the separation of teaching and research could be fully implemented. But there are strong feelings within the universities that such a separation would be destructive. There is also widespread opposition to a rigid three-tier system of universities and at the meeting, Baker said the government will not enforce a three-tier division of universities according to the labels: type $\mathrm{R}$ (with substantial research across all fields); type $X$ (with substantial research in particular fields); and type $\mathrm{T}$ (with just the research necessary to support teaching but without advanced facilities). But it is clearly the government's intention to distribute resources for teaching uniformly and allocate greatly differing funds for research, says Kingman. And Peter Thorpe, secretary of the Advisory Board for the Research Councils which recommended the RTX system, said that the rejection of rigid labelling of the universities does not mean such a system will not evolve. Sir Walter Bodmer, president of the British Association for the Advancement of Science, says that divisions already exist, but stresses that they should not become too rigid.

Baker plans more upheaval within universities which by the end of the century will result in "a distinctly different regime from the one we have now". And the question of whether universities will retain their autonomy did not disappear after the passage through parliament of the 1988 Education Reform Act. In this respect, the drawing up of the arrangements between the universities, the new Universities Funding Council and the government will be crucial. Baker took care to put the "sound and fury" of the last few months behind them and reassured the universities that they "have nothing to fear from the government. We want you with us, not against us."

Baker also said that the universities should increase their efforts to obtain funding from private sources, business and alumni. The CVCP responded with a request for alteration of tax regulations to encourage such donations. The government also wants more emphasis on the consumer - universities should be better tuned to the desires of the students, said Baker.

\title{
Margaret Thatcher's U-turn on support of basic research?
}

\section{London}

THE government must take full responsibility for supporting basic science in Britain; it cannot rely on the private sector to do so. That is usually the cry of the academic community in the face of dwindling resources for scientific research. But last week it came from the Prime Minister, Mrs Margaret Thatcher, in a speech to the Royal Society, which seems to mark a change in government thinking.

崖

\section{IMAGE UNAVAILABLE FOR COPYRIGHT REASONS}

Mrs Thatcher with Sir George Porter, president of the Royal Society, last week.

This government is not renowned for appreciating the importance of basic research. It has continually stressed exploitability and encouraged industry to play a greater role in supporting basic research. But that is changing. Sir Walter Bodmer, president of the British Association for the Advancement of Science, says that a change of attitude can be sensed within the cabinet, particularly in the views of the chief scientific adviser John Fairclough.

And Thatcher's speech last week indicated a significant shift in government thinking, says Denis Noble, president of the pressure group Save British Science.
But the scientific community is not rejoicing yet: there were no specific declarations of increased funding. "We want to see the colour of their money", says Bodmer. Noble agrees that no one will know the government's true intentions until the science budget is set later this year.

The speech was particularly interesting for those concerned about the environment. The greenhouse effect, the ozone layer and acid rain were all subject to the concern of the prime minister last week. Money spent on safeguarding the environment "is money well and necessarily spent", she said, "because the health of our economy and the health of our environment are totally dependent upon each other". "Stable prosperity can be achieved throughout the world provided the environment is nurtured and safeguarded. Protecting this balance of nature is therefore one of the great challenges of the late twentieth century."

Some might be sceptical of the motivation for such concern, coming during a period when the resouces of the Natural Environment Research Council (NERC) have been drastically squeezed, and when Britain is accused of dragging its feet on environmental legislation in Europe. But the chairman of the NERC, Sir Hugh Fish is encouraged by her concern and now expects to see more funding available for research in these areas. His researchers take a less generous view. One called it "all talk", inspired by political motives. But if more resources are forthcoming few will question whether the concern is genuine or not.
Christine McGourty 